\title{
Racialization: A Defense of the Concept
}

\author{
Adam Hochman ${ }^{1}$ \\ Department of Philosophy, Macquarie University, Sydney, Australia \\ https://orcid.org/0000-0002-4106-839X
}

\begin{abstract}
This paper defends the concept of racialization against its critics. As the concept has become increasingly popular, questions about its meaning and value have been raised, and a backlash against its use has occurred. I argue that when "racialization" is properly understood, criticisms of the concept are unsuccessful. I defend a definition of racialization and identify its companion concept, "racialized group." Racialization is often used as a synonym for "racial formation." I argue that this is a mistake. Racial formation theory is committed to racial ontology, but racialization is best understood as the process through which racialized - rather than racial - groups are formed. "Racialization" plays a unique role in the conceptual landscape, and it is a key concept for race eliminativists and anti-realists about race.
\end{abstract}

KEYWORDS racialization; racialized group; race; racial formation; social constructionism about race; racism

\footnotetext{
${ }^{1}$ adam.hochman@mq.edu.au
} 


\section{Introduction}

If there are no biological races, then either race is not real, or it is real but not biological. In either case, we need to abandon the idea that individuals and groups simply belong to races and start thinking in terms of processes. If race is a social kind, we can turn to racial formation theory for an account of the processes through which races are created, inhabited, transformed, and destroyed (Omi and Winant 2015). But if race is not real - if race is best defined as a biological concept which does not refer to anything in the world - then we should probably cease using "race" as a descriptive term.

The concept of racialization is useful because it offers an alternative to "racial formation." Racialization can be understood as the process through which racialized groups, rather than "races," are formed. If there are no races, or if race is a concept that is best eliminated on normative grounds, then the category of the racialized group offers a replacement for racial classification. The idea of racialization can also be of great value politically, as it offers a way for groups that have been understood and treated as inferior "races" to assert and defend themselves collectively, while rejecting the biologization and inferiorization associated with "race."

Nevertheless, there has been, as Karim Murji and John Solomos note in their collection on the topic, "a mini-backlash against the idea of racialization" (Murji and Solomos 2005, 2). The idea has been criticized on a number of grounds, including the following: it is an awkward synonym for racial formation (Goldberg 1992, 560-61); it is hostage to clarity in defining racism, (Rattansi 2005); it has it not replaced the concept of race (Barot and Bird 2001); and it does not denote a precise action (Fields 2001).

This paper offers a response to the critics of the racialization concept. I argue that when racialization is properly defined, the criticisms of the concept are unsuccessful. I define 
racialization as the process through which groups come to be understood as major biological entities and human lineages, formed due to reproductive isolation, in which membership is transmitted through biological descent. When racialization is defined in this way, the criticisms of the concept miss their target.

David Theo Goldberg is correct to observe that "racialization" is often used as a synonym for "racial formation." If the terms were best understood as synonyms, I would agree with the racialization skeptics that the concept is of little value. However, "racialization" and "racial formation" are distinct concepts, representing contrasting metaphysical positions on race. Racial formation forms "races," whereas racialization forms racialized groups. While "racial formation" is a conceptual resource for realists about race, "racialization" is a conceptual resource for anti-realists about race.

This is not a new perspective on racialization. There are other racialization theorists who are anti-realists about race and who use the concept in the way I recommend (Miles 1989; Small 1994; Blum 2002; Darder and Torres 2003; see also Hochman 2017, 2017b). The shift away from an anti-realist interpretation of racialization may be due in part to the fact that Michael Omi and Howard Winant (authors of Racial Formation in the United States, first published in 1994), use "racialization" and "racial formation" as synonyms (Omi and Winant 2015, 247). Given that racial formation theory has gained wide acceptance among race scholars, it is unsurprising that racialization is now commonly thought to form "races" rather than racialized groups.

I begin, in the following section, by offering and defending a definition of racialization. My focus on definition may seem abstract to some readers. As Alana Lentin writes of "race," it is "not of interest for what it is but for what it does" (Lentin 2015, 1404). The same is true of racialization. Yet if we want to know what racialization does, we will also need to know what it $i s$, or we will identify different phenomena as racialization and end up talking past each other 
(the same is true of "race"). If I am right to claim that the criticisms of the racialization concept stem largely from misunderstandings about what racialization is, then the way to respond to the criticisms is to conduct a conceptual analysis.

After defining racialization, I will motivate it as a useful conceptual resource for antirealists and eliminativists about race. If race were real, there would be little need for the concept of racialization: we would speak of racial formation instead. To motivate the concept, I briefly give some normative (eliminativist) and metaphysical (anti-realist) arguments against racial classification.

Finally, I argue that the criticisms of the racialization concept are not successful. When racialization is defined in the way I recommend - and understood as an alternative to the idea of racial formation - the arguments against "racialization" are no longer persuasive. "Racialization" occupies an important conceptual niche, and it is a valuable idea for race eliminativists and anti-realists about race.

\section{What is racialization?}

In this section, I defend a definition of racialization. The concept can be applied to groups, to individuals, to social structures, and - broadly speaking - to a range of other phenomena. While I define each form of racialization, the focus of this paper is the racialization of groups because the criticisms of the concept stem largely from misunderstandings about racialization at this level. I begin by discussing the concept in this sense, before briefly discussing other forms of racialization.

In offering a definition of racialization, my aim is not merely descriptive: to capture how race scholars have been using this term. My aim is ultimately stipulative: to show how the concept ought to be defined and used. A descriptive approach would be unsuccessful because 
"racialization" is not used in the same way by all race scholars. Some use the term in a thin sense, where it is a shallow descriptor or tag applied when a group is explicitly labeled as a "race." Others use the term in a thick sense, where the concept tells us something about how racialized groups are being understood, and so has content.

Whether we give racialization a thin or thick definition makes a difference. How we define the term determines what we identify as racialization. A useful definition of racialization will avoid false positives and negatives. False positives are cases counted as instances of racialization that are not well understood as such. False negatives are cases well understood as instances of racialization that are not counted as such.

On a thin definition, racialization occurs whenever the term "race" is used to describe human groups, regardless of how those groups are understood. A thin definition of racialization is most likely to produce false positives and negatives. Take the following example of a false positive on a thin definition. Before the term race (and its cognates in romance languages) was applied to human breeding groups, it was used to describe trials of speed, fast water currents, and lineages of bishops, kings, and non-human animals (Hannaford 1996). If racialization takes place whenever the term "race" is explicitly applied to human groups, then kings formed a racialized group. This seems like a mistake. I will argue that we ought to understand race as a biological category (but one that fails to refer to anything in the world). A "race" is, conceptually, a kind of breeding group that forms a lineage. There may be lineages of kings, but kings do not form a breeding group.

The example above is one of a false positive, but a thin definition may also produce false negatives. Consider, for example, the possible racialization of Muslims, post 9/11. On a thin definition of racialization, Muslims are not being racialized, simply because it is uncommon to hear or read mention of a "Muslim race." However, as Neil Gotanda argues, the term "Muslim" "has acquired meaning beyond religion and now also describes a racial category: those whose 
ancestry traces to countries where Islam is significant" (Gotanda 2011). To borrow Lawrence Blum's terminology, Muslims appear to be undergoing a process of racialization, and count as a "partially racialized group" (Blum 2002).

A thin definition of racialization is unhelpful because it invokes another contested term, "race." Racialization is not well understood as the process through which a group is labeled as a race. It is better understood as the process through which a group is understood to constitute a race. Therefore, to offer a thick definition of racialization, I first need to define "race." Without a definition of race, we cannot know what racialization is or how to identify it.

But how should race be defined? Is it a biological or a social concept, for instance? Racial formation theory stipulates that "race" is both biological and social (Omi and Winant 2015, 110). The biological side is taken to be an illusion, while the social side is taken to be real. However, if "race" is not a biological or a social kind, as I will argue in the following section, then the idea of racial formation is misleading. The concept of racialization offers an alternative. By making a distinction between "race" and "racialized group," the racialization theorist is able to offer separate terms for what is claimed to be real and what is claimed to be an illusion. "Race" can be understood as a biological category, which fails to refer to anything in the world (Lewontin 1972; Templeton 2013). Racialized groups, on the other hand, are those groups that have been misunderstood to be biological races, and they are very much real (Blum 2010; Hochman 2017b). ${ }^{2}$

\footnotetext{
${ }^{2}$ How should we understand the ontology of racialized groups? Are they real, but social, as is so often claimed about the so-called races? Elsewhere, I have advanced a position that I call "interactive constructionism about racialized groups," according to which racialized groups are real, but cannot be captured by the standard dichotomy between the biological and the social. "Racialized groups are not simply social constructs, they are administrative, biological, cultural, economic, geographic, gendered, historical, lingual, phenomenological,
} 
We can now start to give the concept of racialization some content. A group is racialized when it is understood to be a biological race. This is a step in the right direction, but it is still vague. What is "race" from a biological perspective? This question can be answered by looking at the history of the race concept. There is an emerging consensus that the first theorist to offer a stable scientific definition of race was Immanuel Kant, in the late eighteenth century (see Bernasconi 2001). Kant did not create the category out of thin air. He brought the following elements of the race concept together in a more stable fashion than previous theorists:

1. Races form due to their reproductive isolation

2. Races evolved as major human lineages

3. Races are major biological groups in the present

4. Race is biologically inherited

5. Race is the taxonomic level below species in humans

6. All human populations belong to at least one race

These six elements, taken together, can be used to form a definition of race as a scientific concept.

This definition of race, like my definition of racialization, is intended to be stipulative. It roughly describes how race was defined by early race theorists, such as Kant, and it stipulates that this is how we ought to define race as a biological concept. This definition offers a distinctive and substantive theory about human biological diversity. Other definitions either change the meaning of race so much that they constitute a change in topic or weaken its

political, psychological, religious, and social constructs" (Hochman 2017b, 85). On this account, racialized groups are real, but as interactive constructs, rather than as social or biological kinds. 
meaning to an extent that renders racial naturalism trivial and uninteresting (see Hochman 2016b).

Now that we have a definition of race, we can offer a substantive, thick definition of racialization. A racialized group could be defined as a group that is understood as a race, according to the scientific definition of race above. However, this definition may be too restrictive and produce false negatives. The term "race" was applied, in something approximating its modern meaning, to human "breeding groups" long before it became a scientific concept in the eighteenth century. In fact, elements 1-4 are all pre-modern. In fifteenth-century Spain, Jews and Moors were understood as major biological groups and lineages. They were even labeled as "razas." According to the purity of blood statutes, their identities were not considered alterable through conversion: they were thought to be "in the blood." This was, arguably, the first historical instance of racialization (Nirenberg 2009). Racialization preceded race science.

If fifteenth-century Spanish Jews and Moors are well understood as racialized groups, then we can say that racialization takes place when conditions 1-4 in the list above are met. As such, racialization can be defined as follows: racialization is the process through which a group is understood to be a major biological entity and human lineage, formed due to reproductive isolation, in which membership is transmitted through biological descent. Scientific racialization also involves elements 5 and 6 and produced the kind of racial taxonomy that we recognize today. Kant, for instance, color-coded the so-called races "noble blonde," "copper red," "black," and "olive-yellow" (Kant 1777).

The thick definition of racialization above has the right level of vagueness. It is precise enough that we can, for instance, identify the origins of racialization. Yet it is vague enough that the right things are left open. It does not, for instance, stipulate the racializing agent. This is a task for the racialization scholar. In some cases it will be easy, as with the example of Kant 
above. In other cases, it will be more difficult. Think again of the possible racialization of Muslims, post 9/11. In that case, it may be difficult to specify the exact racializing agent or agents. I take this to be a fact about the world, rather than a problem with the racialization concept.

Now we have a definition of racialization, we might wonder whether this process still occurs. It was shown almost half a century ago that the majority of human genetic diversity resides within, rather than between, the groups commonly called "races" (Lewontin 1972). Nevertheless, there are still specialists who endorse racial naturalism, and while laypeople vary in the extent to which they attribute so-called racial differences to cultural, personal, and biological factors, they still tend to view "race" as a valid biological category (Condit et al. 2004). Racialization is an ongoing process.

Before discussing other forms of racialization, I will make one last clarification. While racialization is often understood as something powerful groups do to others, it is also something groups do to themselves. We can call this process "self-racialization." As Steve Garner writes, it should be 'borne in mind that attaching meaning to one's own group as a 'race,' and instilling this meaning with positive attributes... is a common practice for subordinate groups seeking to defend and assert themselves collectively" (Garner 2009, 20). Self-racialization is also practiced by dominant groups: it can be performed to justify and defend dominant status.

While the focus of this paper is the racialization of groups, there are other forms of racialization. Racialization happens on the individual level, for instance. The processual nature of racialization highlights not only the historically contingent production of racialized groups, but also the developmental and context-dependent production of racialized individuals (Phoenix 2005; Ware 2005). An individual is racialized when they are understood to be a member of a "race" according to the definition of race above (the distinction between scientific and non-scientific racialization applies here as well). Individual racialization is dependent on 
time and place. As Michael Root notes, "Some men who are black in New Orleans now would have been octoroons there some years ago or would be white in Brazil today" (Root 2000, 631$32)$.

Just as groups self-racialize, individuals self-racialize. How one is racialized is not necessarily stable over one's lifetime and depends in part on how one self-racializes. For example, one may be able to pass as belonging to a racialized group one is not usually associated with through a process of self-racialization. This happened in the case of Rachel Dolezal, who presented herself as, and was accepted as, a black woman - an African American - even though she has no recent African ancestry. The fact that racialization on the individual level depends only in part on how one self-racializes is made abundantly clear in this case. Dolezal is no longer racialized as a black woman.

The racialization concept can also be applied to social structures. A social structure is racialized when it reflects the racialization of groups. If there are correlations between racialized groups and a social institution, or some other stable arrangement of social life, that social structure is racialized. This form of racialization runs deep, affecting health care, employment, mortgage lending, and many other social institutions (Smedley and Smedley 2005).

Last, racialization applies to a range of other phenomena. For instance, hairstyles and styles of dance are racialized when they are associated with particular racialized groups (e.g. the high-and-tight, Hitler Youth cut; twerking). As in the other forms of racialization, this does not necessarily happen through conscious effort. It may be important and interesting to know whether racialization is deliberate, but racialization can occur without the deliberate intention to racialize. 
In this section, I defined racialization as a concept that can be applied to groups, individuals, social structures, and other phenomena. ${ }^{3}$ My focus was on the group level because criticisms of the concept focus primarily on that level. I will argue that when racialization is defined in the way I recommend, the criticisms of the concept fail. Before presenting this argument, I will show why we should care - why racialization is a concept worth defending.

\section{Motivating the racialization concept}

As Murji and Solomos observe, "racialization appears sometimes to be a synonym for racial or racist meanings, or to suggest the process by which those meanings are made" (Murji and Solomos 2005, 21). While this is not posed as a criticism of the concept, synonyms are often good candidates for conceptual elimination. For racialization to be a concept worth defending, it ought to play a unique conceptual role.

Many race theorists think of "racialization" as synonymous with "racial formation." Omi and Winant, for example, use the terms synonymously. They write that "Racialization began very early in the United States and never went away, though processes of racial formation have varied greatly across both time and space" (Omi and Winant 2015, 247). Racialization and racial formation are, on this formulation, the same process.

Given the hegemonic status of racial formation theory, it is not surprising that Omi and Winant's usage of the term has spread. According to Laura Gómez, "Racialization refers to the social process by which a racial group comes to exist" (2012). Similarly, Sally Haslanger begins defining racialization by telling us that a "group $\mathrm{G}$ is racialized relative to context $\mathrm{C}$ " and then summarizes by writing, "In other words, races are those groups..." (2012, 236-37).

\footnotetext{
${ }^{3}$ The fact that there are four forms of racialization makes the term ambiguous. However, it should be clear from the context which form is being invoked in any instance, so this ambiguity should not be problematic.
} 
David Theo Goldberg writes "the concept that has assumed wide currency in characterizing the process by which human groups are constituted as races is racial formation (or, more awkwardly, racialization)" (Goldberg 1992, 560-61).

Given the amount of critical attention the racialization concept has attracted, if it is just an "awkward" synonym for racial formation, then perhaps we should eliminate the term from our theoretical toolkit. However, rather than being a synonym of "racial formation," the concept is best understood as a resource for race eliminativists and anti-realists about race. So to motivate racialization as an important concept, I need to motivate eliminativism or antirealism about race. If we could speak unproblematically of race as a biological or a social kind, then there would be little need for the racialization concept. In this section, I briefly offer some metaphysical and normative arguments against racial classification.

I begin with a metaphysical argument against race. Simply, there are no human biological races. I make this claim using the common standard against which the reality of biological race is determined. "Subspecies" has traditionally been considered, at least since Darwin, to be the scientific synonym for "race." When the standard methodologies for identifying subspecies are applied to humans, no subspecies are identified (Templeton 2013). Human biological diversity is too small and too smoothly distributed across geographic space for human subspecies divisions. If "subspecies" is the scientific synonym for 'race,' and there are no human subspecies, then there are no human races. There have been attempts to weaken the definition of race to defend racial naturalism, but I take these to have been refuted (Hochman 2016b). Race, I would argue, is a biological illusion.

If there are no human biological races, it would seem that we should not continue to classify people racially. However, while most race theorists are anti-realists about biological race, they are realists about social race. They justify racial classification by arguing race is a social, not biological, kind. Racial formation theorists, for instance, are committed to a social 
version of racial realism (Omi and Winant 2015, 110). I argue that a social approach to race is problematic on both normative and metaphysical grounds. Let me begin with three normative arguments.

First, non-specialists still understand race biologically (Condit et al. 2004). By giving race a social definition the term becomes ambiguous, and there is risk of miscommunication between specialists and the public. While some scholars distinguish between "biological race" and "social race" (Hardimon 2017), this is not common practice. Most race scholars talk about "race" simpliciter. This is a problem because race-talk is likely to be understood by nonspecialists as biological race-talk, even when the speaker intends "race" to be understood as a social category. As Robert Miles argues, the use of the race concept "is particularly problematic when 'race relations' sociology reports its findings and conclusions to politicians, the media and the public in a historical context in which the nineteenth century idea of 'race' continues to be reproduced" $(1988,10)$. Race-talk is likely, in these contexts, to spread racial naturalism and hereditarianism, even when the speaker really means "social race."

Second, the debate about biological race is not over, so we cannot simply redefine race socially. According to survey studies, belief in the existence of biological races among biologists and anthropologists has been dropping steadily since the 1950s (Lieberman et al. 2004; Wagner et al. 2017). However, interest in racial naturalism seems to be increasing in the post-genomic era (Morning 2011; Bliss 2012; Roberts 2012). We cannot simply assume that all race naturalists are driven by prejudice and can be summarily dismissed. Some surely are, but many have tried to revise the biological notion of race so that it is non-hierarchical, antiessentialist, and fits with current biological knowledge (e.g. Hardimon 2017; Spencer 2018). I find the arguments against racial naturalism convincing (see Templeton 2013; Hochman 2016b), but the debate continues. In short, we cannot simply redefine race socially because we still need a biological definition of race to resolve the debate about racial naturalism. 
Third, a social ontology of race is compatible with racial naturalism and does not entail that race is a biological illusion, which is what most of its proponents want it to do. A social ontology of race introduces a distinction between "biological race" and "social race" but remains quiet on the biological metaphysics. Biological and social races might overlap, they might be different, only one kind of race might exist, or they might both be illusory. While it is often assumed that social constructionism is opposed to racial naturalism, many race naturalists endorse some version of social constructionism about race (e.g. Hardimon 2017). The idea that race is social is not a response to racial naturalism, it is a change in topic. Most social constructionists about race seem to believe that their view contrasts with racial naturalism, but it does not. ${ }^{4}$

These three normative arguments offer practical and political reasons against redefining "race" as "social race" (and for defining race biologically and contrasting "race" with "racialized group"). These problems can be avoided by distinguishing between "biological race" and "social race." While some race scholars already do this, the majority do not. But even if a distinction between "biological race" and "social race" were institutionalized, this would not be enough to justify racial realism. This is because the claim that races are real but social is susceptible to metaphysical critique.

The ontological standards by which "race" is judged socially real are not as developed as those in the biological sciences. Esa Diaz-Leon claims that "Social constructivism about races holds that races are socially real, that is, that races should be identified with socially constructed

\footnotetext{
${ }^{4}$ Sometimes "social constructionism" is used to refer to the weak view that biological racial taxonomy is a product of social factors, and a false imposition onto nature (Gannett 2004; Hochman 2013). However, this view is best described as anti-realism about race. I use social constructionism to refer to the strong view that race is real but social.
} 
properties, or social kinds" $(2015,547)$. But what is a social kind exactly? Ronald Sundstrom offers an account of such kindhood. "A kind," he explains,

is real when its members are unified - held together by a number of shared properties. The properties that unify a kind vary with the domain...A biological kind is unified by some significant biological relation...Similarly, a human [or social] kind is real when unified by a significant social relation. (2002, 95)

I have argued elsewhere that a social kind approach to race is susceptible to a reductio ad absurdum argument (Hochman 2017b). On the standard social kind approach, "race" is thought to be made real by social (and not biological) factors and relations, but it is understood to be produced only under modern conditions of biologization. Following medievalist Geraldine Heng (2011a, 2011b), I argued that the modern forms of biologization associated with racial formation are not necessary for the formation of the sort of social groups that racial formation theorists and social constructionists call "races" (Hochman 2017b; see also Thomas 2010). While for Heng this demonstrates that racial formation took place as early as the thirteenth century in Christian-Jewish relations, for me this shows that when a social approach to race is applied consistently and taken to its logical conclusion, "race" is made transhistorical and is conflated with other categories, such as religion. Thirteenth-century Jews do indeed count as a "race" on a social kind approach to race, but thirteenth-century Jews are better understood as a religious group subject to structural persecution than as a "race." The right conclusion, I proposed, is to reject race as an analytic category altogether.

In this section I have argued that race is a problematic category from both a normative and a metaphysical perspective. My aim has not been to convert the staunchest of race realists, but - more modestly - to show that there are reasons to have an alternative to the language of "racial formation" and "race." 


\section{In defense of the concept of racialization}

The concept of racialization offers an alternative to the concept of racial formation. Its companion concept, racialized group, offers an alternative to the category of race. The concept of the racialized group, unlike "race," has the benefit of highlighting the historical contingency of racialization. As J.L.A. Garcia explains, while a "race" is something one has, "racialization is something that is done to a group, by some social agent, at a certain time, for a given period, in and through various processes, and relative to a particular social context" (Garcia 2003, 285; see also Ludwig 2018). The language of "racialization" is therefore less likely to perpetuate false beliefs about the naturalness of racial classification than standard race-talk. Given this, and the normative and metaphysical arguments against racial classification described in the previous section, we have strong reasons to endorse the concept of racialization as an alternative to the concept of racial formation. Nevertheless, the idea has been subject to increasing critique in recent years. In this section, I reply to the critics of the racialization concept.

Perhaps the most visible and vocal critic of "racialization" is David Theo Goldberg. He writes that "for some years now I have avoided using the very notion, both warning my students that 'racialization' has no purchase and refusing it as an analytic in my own work" (Goldberg $2005,88)$. The claim that racialization has no purchase suggests that racialization is not a real process. However, if racialization is defined as I suggest above, then clearly racialization is real - and has purchase - for the simple reason that there are groups understood to be biological races (Condit et al. 2004).

While Goldberg appears to be making the radical metaphysical claim that racialization does not exist, if we read on it appears that this was not his intention. "I was recently asked by a colleague why this refusal," Goldberg recalls. He responded as follows. "The usage of 
racialization so broadly in the literature is at the very least ambiguous, and may sometimes be vacuous. One cannot always tell, either explicitly or contextually, whether it is being invoked as a merely descriptive term or with deeper normative, critical thrust" (Goldberg 2005, 88, emphasis added).

Before explaining and responding to this criticism, it may be useful to note that this paper is a defense of racialization as a concept. There is a difference between criticizing the concept and criticizing how the concept is sometimes used. Concepts are tools, and like any tool, they can be misused or used ineffectively. Ambiguity or vacuity in some uses of the concept of racialization does not necessarily indicate a problem with the concept itself. If the problem is, as Goldberg states, merely with the "usage of racialization," this usage could be altered. However, if the concept itself were ambiguous or vacuous, that would be a serious problem. Let us reinterpret Goldberg's criticisms of "racialization," then, as aimed at the concept, rather than its use.

The ambiguity concerning Goldberg has to do with whether racialization is a descriptive or normative concept. On my definition of racialization, the term names a process or state of affairs, so racialization is, at least, a descriptive concept. If we focus on groups, to claim that racialization is taking place is to claim that a group is being understood as a biological race in the sense I describe above. Notice that this addresses Goldberg's concern about vacuity. Given that racialization describes a state of affairs, it is not a vacuous or empty concept.

Does the concept of racialization also have a "deeper normative, critical thrust?" Goldberg believes that "racialization...presupposes an answer to a question not even posed: namely, is racial characterization inevitably racist?" (Goldberg 2005, 88). For Goldberg, "racialization" involves a conflation of "race" and "racism." Close association between racialization and racism is a common thread in the literature on racialization. This is not surprising, given that racialization has, historically, gone hand-in-hand with racism. However, 
some critics of racialization believe that the connection is so tight that it causes problems for the racialization concept. Rattansi worries that "the value of the concept of racialization itself is hostage to clarity in defining key terms, especially racism" (Rattansi 2005, 279).

Racialization is indeed hostage to clarity in defining a key term, but I have argued that this term is race (which I define above, defusing the hostage situation), not racism. On my definition of racialization, there is no mention of racial hierarchy. Racialization is, of course, complex in terms of its intents and outcomes (Epstein 2007; Whitmarsh and Jones 2010; Bliss 2012; Kahn 2013). Some race naturalists defend hereditarian claims (e.g., Sesardic 2010; for a response, see Hochman 2013). However, almost all attempts by philosophers of science to defend racial naturalism is either explicitly anti-racist or, at least, does not include any hierarchical component (e.g., Spencer 2014; for a response, see Hochman 2014). Moreover, racialization sometimes occurs in the name of anti-racist medicine, which is why Brett St Louis (2005) argues that racialization is not necessarily tied to racism. ${ }^{5}$ So to respond to Goldberg's worry about ambiguity, racialization is a descriptive concept, rather than a normative concept with some necessary connection to racism. "Racialization" is not ambiguous in the way Goldberg suggests.

"Racialization" has an ontological rather than normative thrust. It throws the reality of race into question (Miles 1989; Small 1994; Blum 2002; Darder and Torres 2003; Hochman 2017b). By using racialization as a synonym for racial formation, scholars have not been asking enough of the concept. Yet there is also a tendency for scholars to ask too much of the concept. Consider Rattansi's criticism of "the inability of racialization to help in differentiating what is and what is not to count as racism, nor how many [racisms] are really important, nor what forces shape and reshape them, nor the strategies that might effect deracialization" $(2005,273)$.

\footnotetext{
${ }^{5}$ For an excellent, succinct rejection of "racial" medicine, see Schwartz (2001)
} 
This is asking too much of the concept. "Racialization" tells us that groups are being understood as biological races. It cannot tell us what racism is: only a definition of racism can help do that. Nor can "racialization" tell us how many forms of racism exist, or which forms are most important, let alone tell us how to deracialize the world. It is not clear that these are even things that a concept can do.

Similarly, Barot and Bird want to know, "Concretely, is the designation racialization now the essential concept which can, for sociologists, provide the key to understanding forms of racial discrimination and racial hatred?" (Barot and Bird 2001, 602). They believe that it is not, but again, this is asking too much from "racialization." On my definition of the concept, racialization is a form of biologization. As it does not even tell us whether racism is taking place, it could not be the key to understanding racism.

Barot and Bird seem, at times, to expect that racialization ought to be the master concept that will render irrelevant all of those concepts that came before. They lament that "There is still an enormous conceptual armanentarium in sociology to write and talk about issues of race and ethnicity: race, racism, raciation, racialism, racialization, 'race,' ethnicity, ethnicism and so on" (Barot and Bird 2001, 616). Yet these distinctions are important. They help race and ethnicity scholars think clearly, with nuance, about the topics on which we work. Racialization cannot and should not replace these concepts, even if some of them - race and raciation - are empty.

Barot and Bird worry that "although the term [racialization] is used instead of the term race, 'race' is still widely in use" (Barot and Bird 2001, 613). The implication seems to be that if the racialization concept were really useful, we could do away with the term "race." For Barot and Bird, the confinement of the term "race" in scare quotes suggests "an almost Derridean desire to erase the concept but leave it there" (Barot and Bird 2001, 613). However, this convention merely alerts the reader that "race" is a category in question, an object of 
skepticism. We would still need to talk about "race" even if we could all agree that race is not real, and even if classification in terms of racialized groups replaced racial classification entirely. The concept of phlogiston remains, even though it was superseded by Lavoisier's oxygen theory. Most of us have no reason to talk about phlogiston, but we do need to talk about - and teach about - "race." Only in a distant, utopian future is it imaginable that we could stop talking about "race" without repeating the injustices of the past.

Another example of a "racialization" critic asking too much of the concept can be found in Barbara Fields' incisive article Whiteness, Racism, and Identity. Fields writes that,

racialize, like most adjectives passing for verbs, does not denote a precise action. What, exactly, do scientists, immigration officials, ballot reformers, intelligence testers, newspaper cartoonists, employers and potential employers, WASP snobs, and middle- and working-class nativists do when they racialize immigrants? The question itself is part of the answer: Not all racializers do the same thing when they racialize (Fields 2001, 50).

On my definition of racialization above, racializers do not perform a "precise action." Rather, they cause a specific outcome: they cause groups to be understood as major biological entities and human lineages, formed due to reproductive isolation, in which membership is transmitted through biological descent. It is actually a benefit of my definition that I do not attempt to define racialization in terms of a "precise action" for the very reason Fields suggests: racialization works differently in different contexts and depending on who is doing the racializing (on differential racialization, see Brah 1996). Fields' critique is best interpreted as a criticism of the way some scholars use the term racialization. That is, Fields may be read as voicing the following concern. Some scholars use the term racialization as if all racializers do the same thing when they racialize, which is not true. However, this would be another example of a problem with how the concept is used, rather than a problem with the concept itself. 
Another worry one might have about "racialization" - or rather its product, "racialized groups" - is that the idea is susceptible to the kind of critique that Rogers Brubaker offers against "groupism":

In the domain of ethnicity, nationalism and race, I mean by 'groupism' the tendency to treat ethnic groups, nations and races as substantial entities to which interests and agency can be attributed. I mean the tendency to reify such groups....as if they were internally homogeneous, externally bounded groups, even unitary collective actors with common purposes. I mean the tendency to represent the social and cultural world as a multichrome mosaic of monochrome ethnic, racial or cultural blocs. (Brubaker 2002, 164)

Does the category of the racialized group lend itself to this kind of "groupist" thinking? I believe not. In fact, it can serve as a bulwark against such reification. The fact that racialization is something, as Garcia points out in the quote above, that is "done to a group," highlights the fallacy of groupism $(2003,285)$. There is no reason to assume, for example, that racialized groups will be culturally uniform. Rather, given that racialization is a process through which large populations are falsely biologized, it would be rational to assume that such groups house great cultural diversity. ${ }^{6}$

Those are, in my reading of the literature, the major criticisms of the concept of racialization. When racialization is defined in the way I suggest, none stands up to critical scrutiny.

\footnotetext{
${ }^{6}$ I thank an anonymous reviewer for suggesting this potential problem with the racialization concept.
} 


\section{Conclusion}

This paper offered a defense of the racialization concept against a number of critiques. Because the critiques involve misunderstandings about what racialization is, I began by offering and defending a definition of racialization. To motivate the concept of racialization as an alternative to "racial formation," I offered some reasons to be skeptical about racial realism on both normative and metaphysical grounds. Finally, I defended the concept of racialization against its critics. The criticisms can be dealt with quite easily when racialization is defined as I suggest, contrasted with "racial formation," and paired with its companion concept, racialized group.

The racialization concept is not the key that will solve all of our racial ills, as some of its critics seem to have hoped. Nevertheless, it is a very useful concept for race skeptics. By, for instance, warning students against the racialization concept, one may frighten them off using one of the most valuable conceptual resources available for the study of this important and fraught topic.

\section{Acknowledgements}

I would like to thank Frances Olive for her helpful comments on an earlier draft. Thanks also to two anonymous referees for their useful feedback. 


\section{References}

Barot, Rohit, and John Bird. 2001. "Racialization: The Genealogy and Critique of a Concept." Ethnic and Racial Studies 24 (4): 601-618.

Bernasconi, Robert. 2001. "Who Invented the Concept of Race? Kant's Role in the Enlightenment Construction of Race.” In Race, edited by Robert Bernasconi, 11-36. Blackwell Publishers.

Bliss, Catherine. 2012. Race Decoded: The Genomic Fight for Social Justice. Stanford, CA: Stanford University Press.

Blum, Lawrence. 2002. “I'm Not a Racist, but...” The Moral Quandary of Race. Ithaca, NY: Cornell University Press.

- - - 2010. "Racialized Groups: The Sociohistorical Consensus." The Monist 93 (2): 298320.

Brah, Avtar. 1996. Cartographies of Diaspora: Contesting Identities. London: Routledge. Brubaker, Rogers. 2002. "Ethnicity without Groups.” European Journal of Sociology 43 (2): $163-89$.

Condit, Celeste M., Roxanne L. Parrott, Tina M. Harris, John Lynch, and Tasha Dubriwny. 2004. "The Role of 'Genetics' in Popular Understandings of Race in the United States." Public Understanding of Science 13 (3): 249-72.

Darder, Antonia, and Rodolfo D Torres. 2003. "Shattering the 'Race' Lens: Toward a Critical Theory of Racism." In The Critical Pedagogy Reader, edited by Antonia Darder, Marta Baltodano, and Rodolfo D Torres, 245-61. New York: RoutledgeFalmer. Diaz-Leon, Esa. 2015. “In Defence of Historical Constructivism about Races.” Ergo, an Open Access Journal of Philosophy 2 (21): 547-62. 
Epstein, Steven. 2007. Inclusion: The Politics of Difference in Medical Research. Chicago: University of Chicago Press.

Fields, Barbara J. 2001. "Whiteness, Racism, and Identity.” International Labor and Working-Class History 60: 48-56.

Gannett, Lisa. 2004. “The Biological Reification of Race.” The British Journal for the Philosophy of Science 55 (2): 323-45.

Garcia, Jorge L A. 2003. “Three Scalarities: Racialization, Racism, and Race.” Theory and Research in Education 1 (3): 283-302.

Garner, Steve. 2009. Racisms: An Introduction. London: SAGE Publications.

Goldberg, David Theo. 1992. "The Semantics of Race.” Ethnic and Racial Studies 15 (4): $543-69$.

- - - 2005. "Racial Americanization.” In Racialization: Studies in Theory and Practice, edited by Karim Murji and John Solomos, 87-102. New York: Oxford University Press.

Gómez, Laura E. 2012. "Looking for Race in All the Wrong Places.” Law \& Society Review 46 (2): 221-45.

Gotanda, Neil. 2011. "The Racialization of Islam in American Law." The ANNALS of the American Academy of Political and Social Science 637: 184-95.

Hannaford, Ivan. 1996. Race: The History of an Idea in the West. Washington: Woodrow Wilson Center Press.

Hardimon, Michael O. 2017. Rethinking Race: The Case for Deflationary Realism. Harvard University Press.

Haslanger, Sally. 2012. Resisting Reality: Social Construction and Social Critique. New York: Oxford University Press. 
Heng, Geraldine. 2011a. "The Invention of Race in the European Middle Ages i: Race Studies, Modernity, and the Middle Ages." Literature Compass 8 (5): 315-31. - - . 2011b. "The Invention of Race in the European Middle Ages II: Locations of Medieval Race." Literature Compass 8 (5): 332-50.

Hochman, Adam. 2013. "Racial Discrimination: How Not to Do It." Studies in History and Philosophy of Biological and Biomedical Sciences 44 (3): 278-86.

- - - . 2014. "Unnaturalised Racial Naturalism." Studies in History and Philosophy of Biological and Biomedical Sciences 46: 79-87.

- - - 2016. "Race: Deflate or Pop?" Studies in History and Philosophy of Biological and Biomedical Sciences 57: 60-68.

- - . 2017a. "In Defense of the Metaphysics of Race." Philosophical Studies 174 (11): $2709-29$.

- - - 2017b. "Replacing Race: Interactive Constructionism about Racialized Groups.” Ergo 4 (3): 61-92.

Kahn, Jonathan. 2013. Race in a Bottle: The Story of BiDil and Racialized Medicine in a Post-Genomic Age. New York: Columbia University Press.

Kant, Immanuel. 1777. "Of the Different Human Races.” In The Idea of Race, edited by Robert Bernasconi and Tommy L Lott, 8-22. Indianapolis: Hackett Publishing. Lentin, Alana. 2015. “What Does Race Do?” Ethnic and Racial Studies 38 (8): 1401-1406. Lewontin, Richard. 1972. “The Apportionment of Human Diversity.” In Evolutionary Biology, edited by Theodosius Dobzhansky, Max K. Hecht, and William C. Steere, 6:381-98. New York: Meredith Publishing Company.

Lieberman, Leonard, Katarzyna A. Kaszycka, Antonio J. Martinez Fuentes, Leonid Yablonsky, Rodney C. Kirk, Goran Štrkalj, Qian Wang, and Li Sun. 2004. “The Race 
Concept in Six Regions: Variation without Consensus." Collegium Antropologicum 28 (2): 907-921.

Ludwig, David. 2018. "How Race Travels: Relating Local and Global Ontologies of Race." Philosophical Studies. https://doi.org/10.1007/s11098-018-1148-x.

Miles, Robert. 1988. "Beyond the 'Race' Concept: The Reproduction of Racism in England." Sydney Studies in Society and Culture 4: 7-31.

- - . 1989. Racism. London: Routledge.

Morning, Ann. 2011. The Nature of Race: How Scientists Think and Teach about Human Difference. Berkeley, CA: University of California Press.

Murji, Karim, and John Solomos. 2005. Racialization: Studies in Theory and Practice. New York: Oxford University Press.

Nirenberg, David. 2009. 'Was There Race before Modernity? The Example of 'Jewish' Blood in Late Medieval Spain." In The Origins of Racism in the West, edited by Miriam Eliav-Feldon, Benjamin Isaac, and Joseph Ziegler, 232-64. Cambridge: Cambridge University Press.

Omi, Michael, and Howard Winant. 2015. Racial Formation in the United States. 3rd ed. New York: Routledge.

Phoenix, Ann. 2005. "Remembered Racialization: Young People and Positioning in Differential Understandings.” In Racialization: Studies in Theory and Practice, edited by Karim Murji and John Solomos, 103-22. New York: Oxford University Press.

Rattansi, Ali. 2005. "The Uses of Racialization: The Time-Spaces and Subject-Objects of the Raced Body." In Racialization: Studies in Theory and Practice, edited by Karim Murji and John Solomos, 271-301. New York: Oxford University Press.

Roberts, Dorothy. 2012. Fatal Invention: How Science, Politics, and Big Business Re-Create Race in the Twenty-First Century. New York: The New Press. 
Root, Michael. 2000. "How We Divide the World." Philosophy of Science 67: S628-39.

Schwartz, Robert S. 2001. "Racial Profiling in Medical Research.” New England Journal of Medicine 344 (18): 1392-93.

Sesardic, Neven. 2010. "Race: A Social Destruction of a Biological Concept." Biology and Philosophy 25 (2): 143-62.

Small, Stephen. 1994. Racialised Barriers: The Black Experience in the United States and England in the 1980's. London: Routledge.

Smedley, Audrey, and Brian Smedley. 2005. "Race as Biology Is Fiction, Racism as a Social Problem Is Real.” American Psychologist 60 (1): 16-26.

Spencer, Quayshawn. 2014. "The Unnatural Racial Naturalism.” Studies in History and Philosophy of Biological and Biomedical Sciences 46: 38-43.

- - - 2018. "Racial Realism I: Are Biological Races Real?” Philosophy Compass 13 (1): $1-13$.

St Louis, Brett. 2005. "Racialization in the 'Zone of Ambiguity." In Racialization: Studies in Theory and Practice, edited by Karim Murji and John Solomos, 29-50. New York: Oxford University Press.

Sundstrom, Ronald R. 2002. "Race as a Human Kind." Philosophy \& Social Criticism 28 (1): $91-115$.

Templeton, Alan. 2013. "Biological Races in Humans." Studies in History and Philosophy of Biological and Biomedical Sciences 44 (3): 262-271.

Thomas, James M. 2010. "The Racial Formation of Medieval Jews: A Challenge to the Field." Ethnic and Racial Studies 33 (10): 1737-1755.

Wagner, Jennifer K., Joon-Ho Yu, Jayne O. Ifekwunigwe, Tanya M. Harrell, Michael J. Bamshad, and Charmaine D. Royal. 2017. “Anthropologists’ Views on Race, Ancestry, and Genetics.” American Journal of Physical Anthropology 162: 318-327. 
Ware, Vron. 2005. “The Power of Recall: Writing Against Racial Identity.” In Racialization: Studies in Theory and Practice, edited by Karim Murji and John Solomos, 123-40. New York: Oxford University Press.

Whitmarsh, Ian, and David S. Jones, eds. 2010. What's the Use of Race?: Modern Governance and the Biology of Difference. Cambridge, MA: The MIT Press. 